\section{Diyala Journal of Engineering Sciences \\ Journal homepage: https://en.enginmag.uodiyala.edu.iq/}



of Engineering Sciences

ISSN: 1999-8716 (Print); 2616-6909 (Online)

\title{
The Effect of Adding Shear Connectors to the Composite Slabs with Different Geometry of Profile Steel Sheet
}

\author{
Ibrahim A. Ali ${ }^{*}$, Amer M. Ibrahim, Teeba A. Jassim \\ Department of Civil Engineering, College of Engineering, University of Diyala, 32001 Diyala, Iraq
}

\section{ARTICLE INFO}

Article history:

Received 17 February 2021

Accepted 8 June 2021

Keywords:

Composite slabs; Shear connectors; Profile steel sheet; End slip; Longitudinal shear mode of failure

\begin{abstract}
\end{abstract}
\section{Introduction}

Nowadays, the composite slab systems are most widely used in industry buildings or multistorey buildings. The composite deck slab in which the steel sheets are used initially as a permanent formwork to support the weight of concrete and subsequently when concrete hardened the steel decking acts compositely with hardening concrete as a tensile member to resistance the load applied on the floor [1]. The composite slab offers many advantages such as speed in construction, saving in time construction, weight reduction and sustainable section and other advantages listed by $[2,3,4]$. The behavior of the steel sheet-concrete interface is a very complex phenomenon for the design of the composite slab [5]. The longitudinal shear failure considers the most common type of failure which occurs due weak bond between steel sheet and concrete [6,7]. It is very important to improve the composite action resistance of composite slabs because it has clear influences on the strength, stiffness, mode of failure and structural performance of composite slab. Many researchers conducted to evaluate and improve the behaviour of the longitudinal shear resistance and shear connection between profile steel sheet and concrete of composite slab under the flexural loading by using different techniques such as $[8,9,10]$. Normally, the

* Corresponding author.

E-mail address: ibrahimabbas790@gmail.com

DOI: $10.24237 /$ djes.2021.14201 
longitudinal shear resistance can be developed by many factors which are: (i) Mechanical interlock (ii) Friction interlock between steel sheet and concrete (iii) Stud connectors (iv) End deformation of the ribs $[11,12]$.

In this study, the effect of adding shear connectors to the composite slabs which have varies geometries of steel sheet were studied experimentally. Six full-scale specimens of composite slabs were casted and tested under four-point load to obtain the ultimate load, deflection, longitudinal end slip, strain of concrete and steel sheet, energy absorption and type of failure.

\section{Research methodology}

This research is an experimental work conducted in order to investigate the structural behavior of adding shear connectors to composite reinforced concrete one-way slabs.

The experimental program consists of casting and testing six specimens of composite slabs, this research end by discussing the result according to ultimate load capacity, loaddeflection response, load-strain development in concrete and profile steel sheet, longitudinal slip between concrete and profile steel sheet, energy absorbing, and mode of failure. The main parameter were the presence and absence of shear connectors and the geometries of profile steel sheet (trapezoidal shape, triangle shape and T-shape).

\section{Description of the specimens}

Figure 1 shows the cross-section configuration of all the composite deck slab specimens. This study contents of six specimens of composite slabs with dimensions ( $1850 \times 500$ x $110 \mathrm{~mm}$ ) which casted and tested under fourpoint load. Three specimens were without shear connectors with varies types of geometries from profile steel sheets (trapezoidal, triangle and Tshapes) with variation in cross-section area by about $(3 \%-3.5 \%)$ used as references. Other three specimens of composite slabs content four shear connectors (headed stud) in each support because of the maximum slip occur in the end, near to the support therefore the shear connectors add in each support to increase the composite action. Figure 2 shows the arrangement of shear connectors in composite slab.

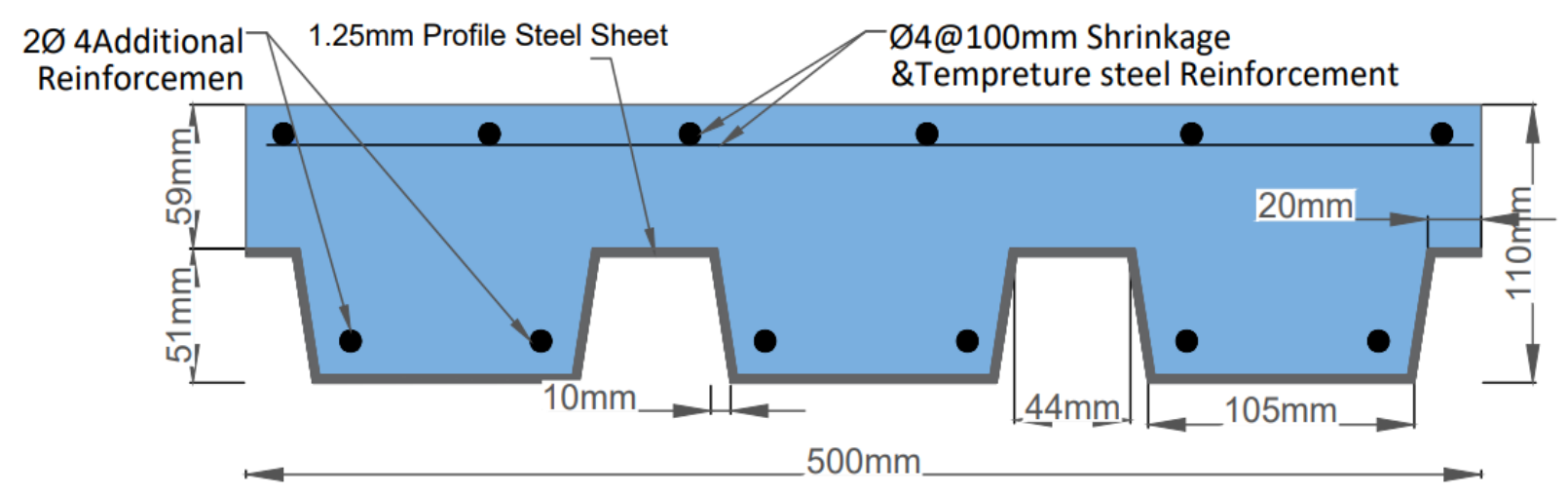

(a) Composite slab with trapezoidal shape of steel sheet without headed stud (CS1) 


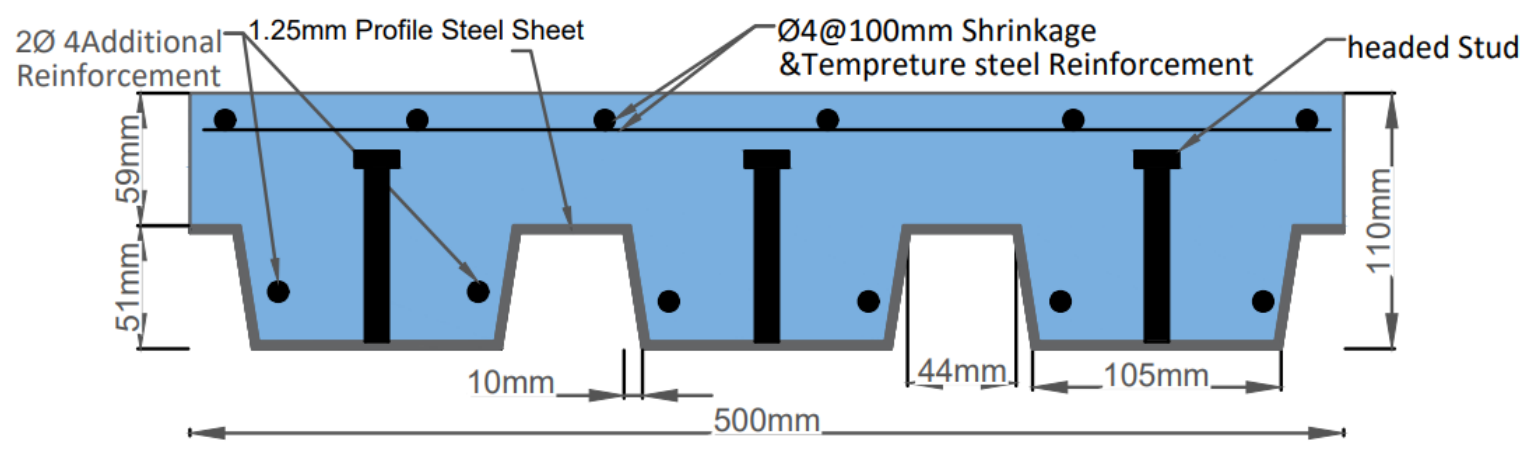

(b) Composite slab with trapezoidal shape of steel sheet with headed stud (CS1s)

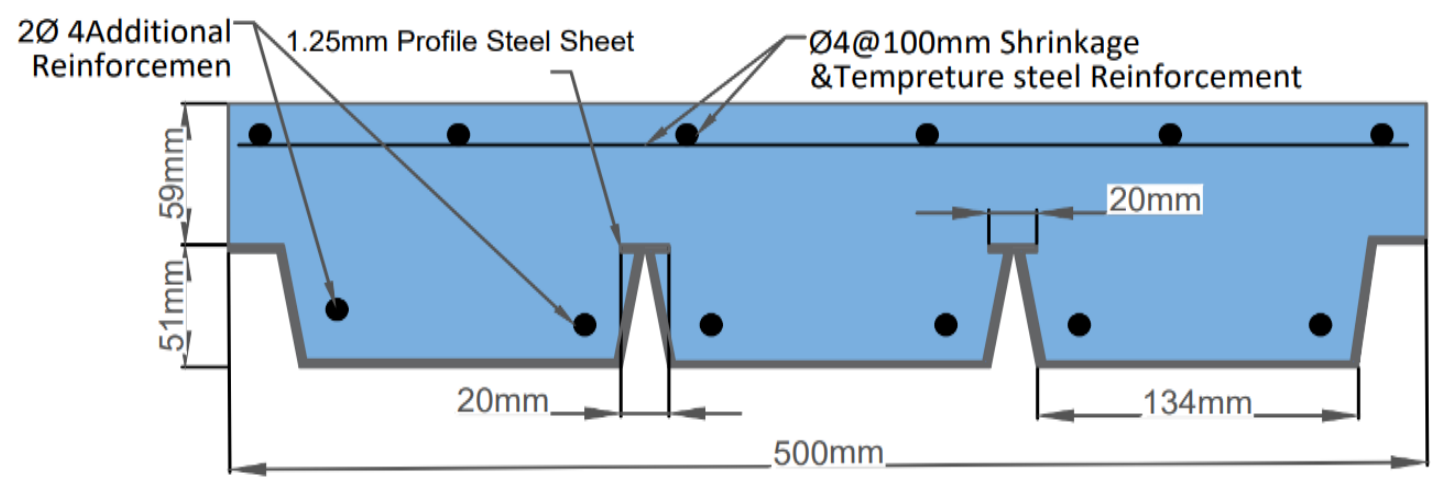

(c) Composite slab with triangle shape of steel sheet without headed stud (CS2)

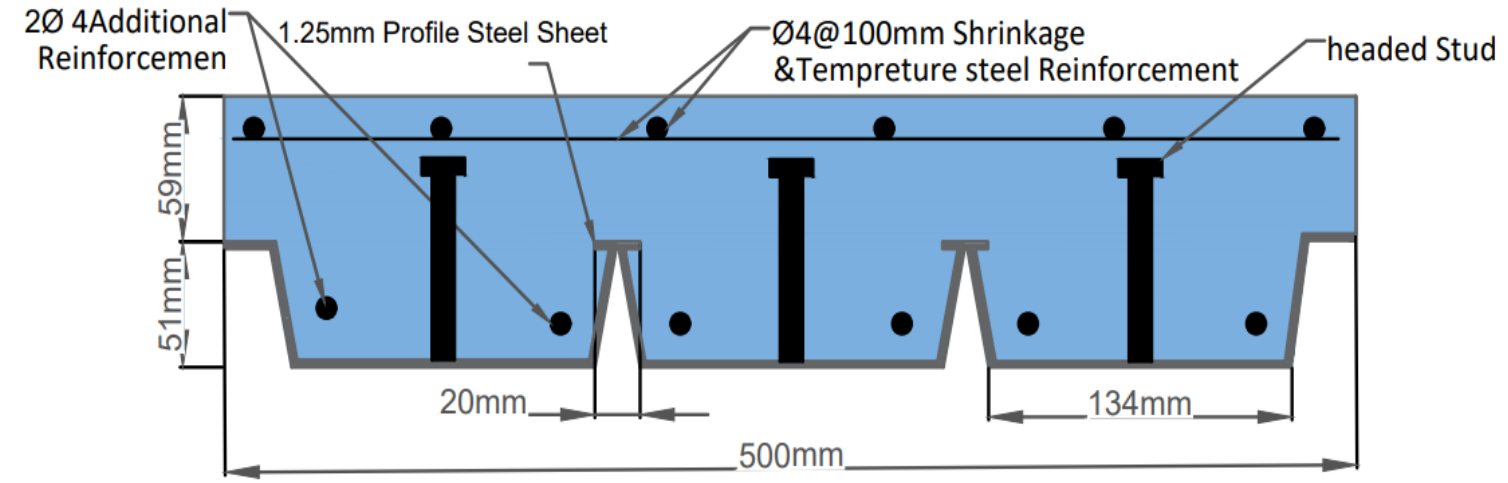

(d) Composite slab with triangle shape of steel sheet with headed stud (CS2s)

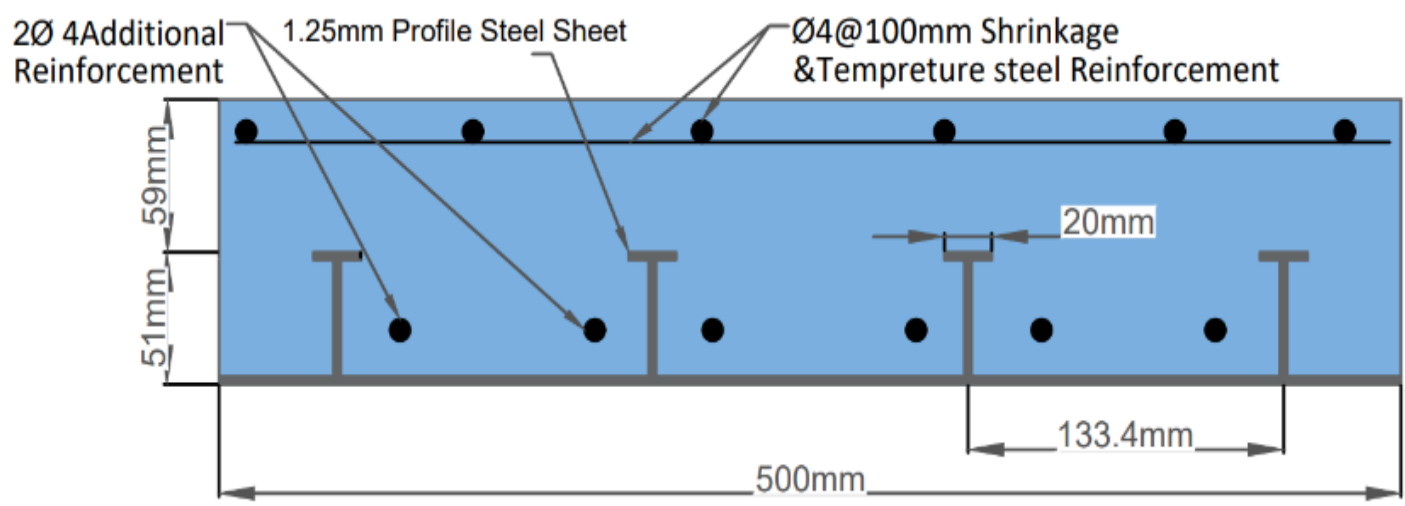

(e) Composite slab with T-shape of steel sheet without headed stud (CS3) 


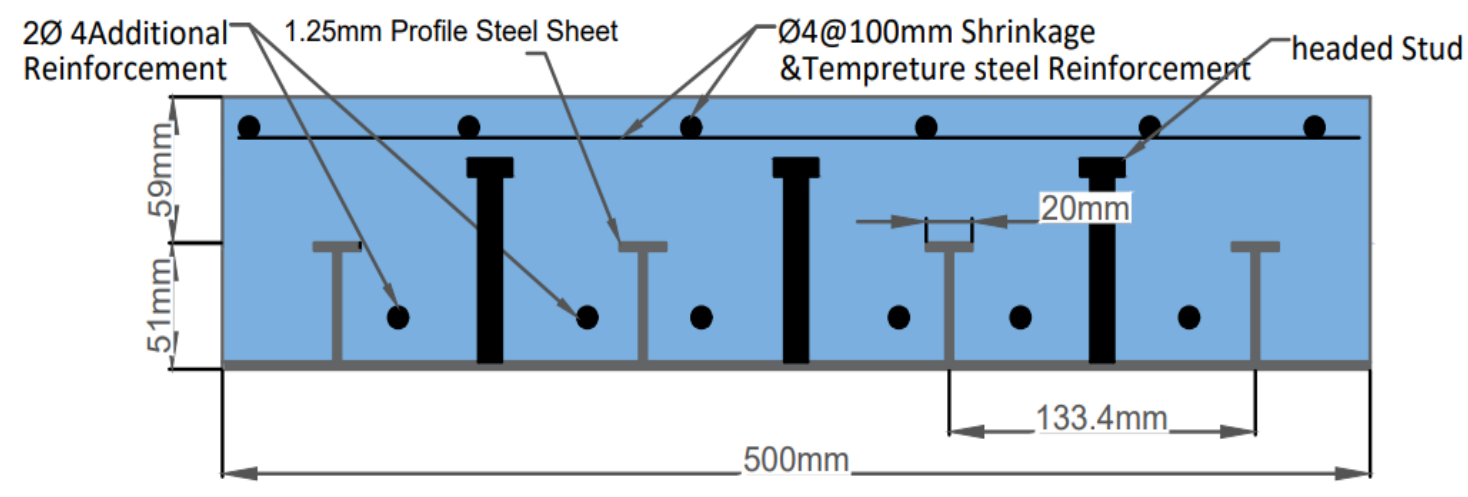

(f) Composite slab with T-shape of steel sheet with headed stud (CS3s)

Figure 1. Cross-sections details of the composite slab's specimens

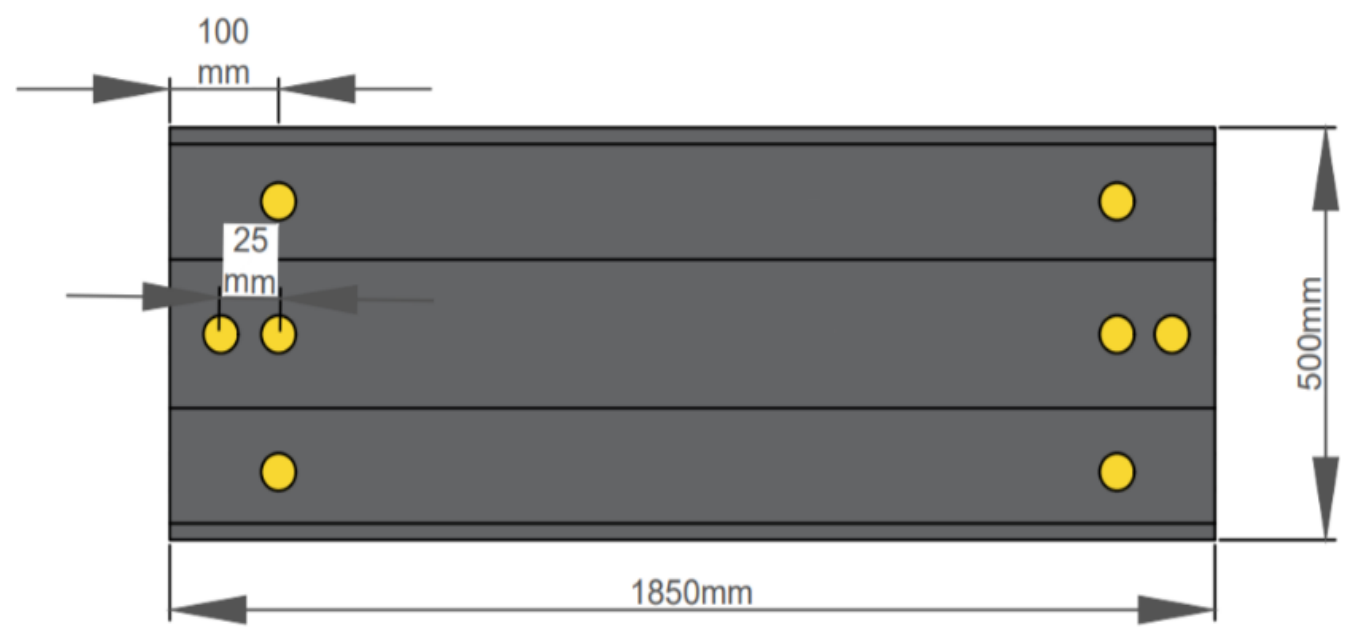

Figure 2. Shows arrangement of shear connectors (headed stud)

\section{Experimental work}

\subsection{Materials}

In this study, self-compacted concrete was used to cast all the six specimens of composite slabs with compressive strength $\left(f_{c}^{\prime}=25\right.$ and $\mathrm{fcu}=30 \mathrm{MPa})$ design according to [13]. Table 1 presents the mix proportions of concrete. The steel sheets that used in this study gained from Ukrainian source with cold rolling and. Three types of geometries of steel sheets were manufactured in this work (trapezoidal, triangle and T-shapes) that were approximately equal in cross section area of steel AP $=(940 \mathrm{~mm} 2$, $973 \mathrm{~mm} 2$ and $968 \mathrm{~mm} 2$ ) respectively with variation by about $(3 \%-3.5 \%)$. All the profile steel sheets are fabricated in Iraq at a local factory as shown in Figure 3. The steel sheets are tested according to [14] Specification, the yield stress and ultimate stress are shown in the table 2. Bar reinforcement with a diameter of $4 \mathrm{~mm}$ were used for control shrinkage and temperature and used in the ribs, the yield stress $(\mathrm{Fy}=442 \mathrm{MPa})$ and ultimate stress $(\mathrm{fu}=620 \mathrm{MPa})$.

The headed stud shear connectors were used in this study in order to increase the composite action with profile steel sheet and concrete and permit to transmit the longitudinal shear between these two materials, Table 3 shows the mechanical properties of stud. The typical dimensions of stud were $10 \mathrm{~mm}$ diameter of stud and $75 \mathrm{~mm}$ overall height, headed diameter was $19 \mathrm{~mm}$ and its height $7 \mathrm{~mm}$. Figure 4 shows the stud headed shear connectors. 
Table 1. Mix proportions

\begin{tabular}{cccccc}
$\begin{array}{c}\text { Water } \\
\left(\mathbf{L} / \mathbf{m}^{3}\right)\end{array}$ & $\begin{array}{c}\text { Cement } \\
\left(\mathbf{K g} / \mathbf{m}^{\mathbf{3}}\right)\end{array}$ & $\begin{array}{c}\text { Lime stone } \\
\left(\mathbf{K g} / \mathbf{m}^{\mathbf{3}}\right)\end{array}$ & $\begin{array}{c}\text { Fine aggregate } \\
\left(\mathbf{K g} / \mathbf{m}^{3}\right)\end{array}$ & $\begin{array}{c}\text { Coarse aggregate } \\
\left(\mathbf{K g} / \mathbf{m}^{\mathbf{3}}\right)\end{array}$ & $\begin{array}{c}\text { s.p } \\
\left(\mathbf{K g} / \mathbf{m}^{\mathbf{3}}\right)\end{array}$ \\
\hline 205 & 430 & 200 & 760 & 700 & 2.5
\end{tabular}

Table 2. Properties of steel plate

\begin{tabular}{|c|c|c|c|c|}
\hline $\begin{array}{c}\text { Normal thickness } \\
(\mathbf{m m})\end{array}$ & $\begin{array}{c}\text { Measure thickness } \\
(\mathbf{m m})\end{array}$ & Yield stress (MPa) & $\begin{array}{c}\text { Ultimate stress } \\
(\mathbf{M P a})\end{array}$ & $\begin{array}{c}\text { Modulus of } \\
\text { Elasticity }(\mathbf{G P a})\end{array}$ \\
\hline 1.25 & 1.24 & 228 & 340 & 200 \\
\hline
\end{tabular}

Table 3. Show the mechanical properties of headed stud

\begin{tabular}{|l|l|l|l|}
\hline $\begin{array}{l}\text { Mechanical Properties of } \\
\text { Head Stud Connector }\end{array}$ & Yield Strength (MPa) & Tensile Strength (MPa) & Max. Elongation \% \\
\cline { 2 - 4 } & 350 & 450 & 15 \\
\hline
\end{tabular}

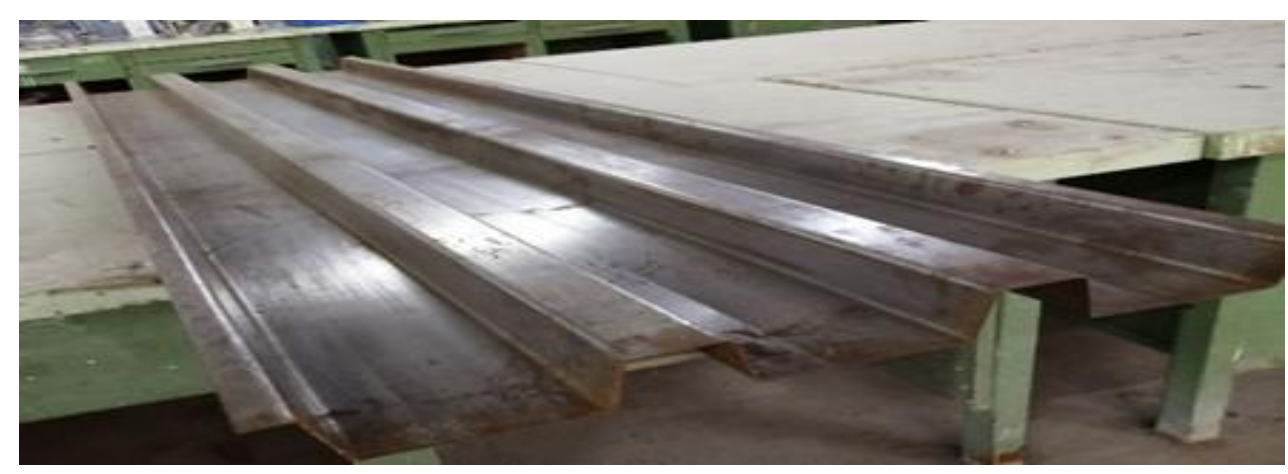

(a) Profile steel sheet with trapezoidal shape



(b) Profile steel sheet with triangle shape

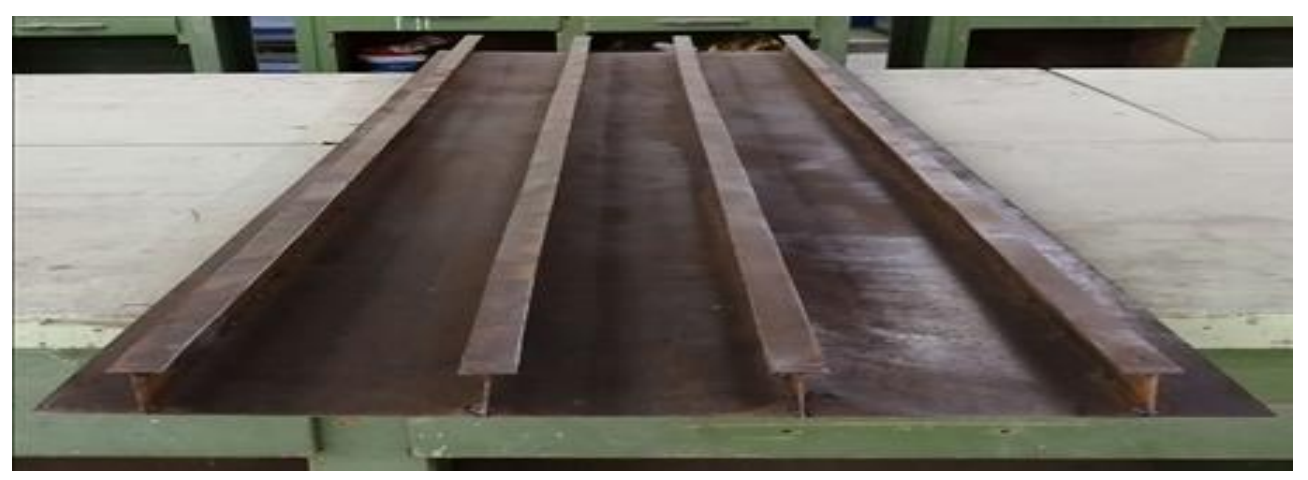

(c) Profile steel sheet triangle shape

Figure 3. Geometry of profile steel sheets 


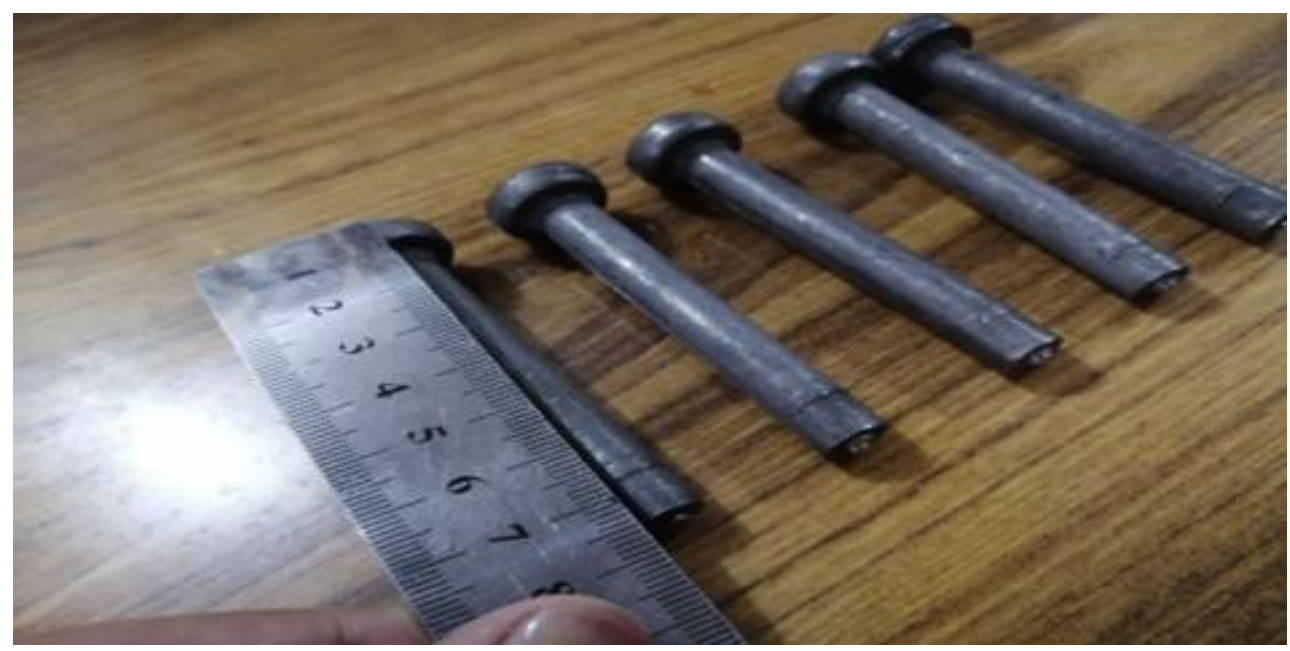

Figure 4. The stud headed shear connectors

Table : : Show the mechanical properties of headed stud

\begin{tabular}{|c|c|c|c|}
\hline $\begin{array}{c}\text { Mechanical Properties of } \\
\text { Head Stud Connector }\end{array}$ & $\begin{array}{c}\text { Yield Strength } \\
\text { (MPa) }\end{array}$ & $\begin{array}{c}\text { Tensile Strength } \\
\text { (MPa) }\end{array}$ & $\begin{array}{c}\text { Max. Elongation } \\
\text { \% }\end{array}$ \\
\cline { 2 - 4 } & 350 & 450 & 15 \\
\hline
\end{tabular}

\subsection{Testing procedure}

The composite slab specimens are tested after (30 days). They are prepared, cleaned and coated with a white colour in order to reveal of possible cracks. The composite slabs are simply supported over a clear span of $1650 \mathrm{~mm}$ and are tested under four point-load applied at the third points. Two LVDTS were used to measure deflection, One of the LVDTS was measured the vertical deflection in the midspan of composite sabs and the other in the side measures the horizontal deflection (horizontal slip) between profile steel sheet and concrete. The six strain gauges are used, three strain gauges were directly attached to the bottom of profile steel sheet surface. One of them is in the midspan and the other two are at one third of span (under the point load). While three strain gauges were placed to the top of composite slab on concrete, all three-strain gage were in the midspan. All strain gauges are connected to the data logger (TDS-530). Figure 5 shows the machine that used for test of specimens.

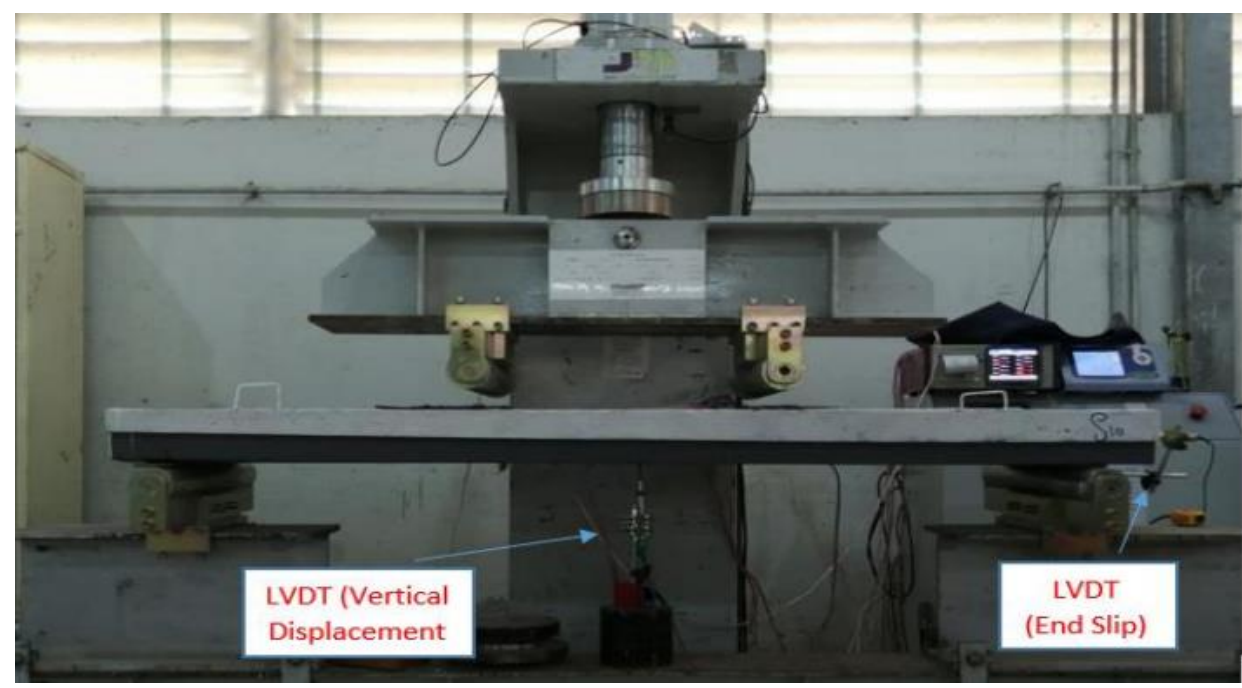

Figure 5. Machine for testing composite slabs 


\section{Experimental results}

\subsection{Ultimate load capacity}

Table 4 shows the ultimate load capacity and other results of all the tested composite slabs. The ultimate load capacity of composite slabs specimens with triangle shape and T-shape were more than ultimate load capacity of composite slab with trapezoidal shape due to the shape of profile steel sheet with triangle and T-shape act to increase interlock between concrete and profile steel sheet. As well as presence of shear connectors in composite slabs specimens act to increase ultimate load capacity as compared with the same shape of profile steel sheet. The ultimate load capacity of composite slabs with trapezoidal shape, triangle shape and T-shape in presence of shear connectors were more than absence of shear connectors by $(22.2 \%, 17.8 \%$ and $2.86 \%$ ) respectively. There are clear effect of adding shear connectors to composite slabs with trapezoidal shape and triangle shape due to the shear connectors act to increase composite action between steel sheet and concrete and that lead to increase horizontal shear resistance but the effected of adding shear connectors to composite slabs with T-shape was little or can neglected it due to the shape of ribs act as a shear connection and that inducted the composite slab with T-shape does not need to shear connectors. It can be indicated that the adding shear connectors to the composite deck slabs does not influence on the failure mode.

Table 4. The results of tested composite slabs

\begin{tabular}{|c|c|c|c|c|c|c|c|c|c|}
\hline $\begin{array}{c}\text { Slab } \\
\text { Symbol }\end{array}$ & $\mathbf{P}_{\mathbf{y}}(\mathbf{k N})$ & $\begin{array}{c}\Delta_{\mathbf{y}} \\
(\mathbf{m m})\end{array}$ & $\begin{array}{c}\mathbf{P}_{\mathrm{u}} \\
(\mathbf{k N})\end{array}$ & $\begin{array}{c}\text { Increase in } \\
\text { Ultimate } \\
\text { load \% }\end{array}$ & $\begin{array}{c}\Delta_{\mathbf{u}} \\
(\mathbf{m m})\end{array}$ & $\begin{array}{c}\text { Ductility } \\
\qquad \Delta_{\mathbf{u}} / \Delta_{\mathbf{y}}\end{array}$ & $\begin{array}{l}\text { Maximum } \\
\text { Slip(mm) }\end{array}$ & Type of Failure & $\begin{array}{l}\text { Failure } \\
\text { Mode }\end{array}$ \\
\hline $\mathrm{CS} 1$ & 30.8 & 11.9 & 45 & ------ & 44 & 3.70 & 4.876 & $\begin{array}{l}\text { Longitudinal } \\
\text { shear failure }\end{array}$ & Ductile \\
\hline $\mathrm{CS} 1 \mathrm{~s}$ & 37 & 8.39 & 55 & 22.2 & 22.85 & 2.72 & 6.404 & $\begin{array}{l}\text { Longitudinal } \\
\text { shear failure }\end{array}$ & Ductile \\
\hline $\mathrm{CS} 2$ & ----- & ----- & 59.4 & ----- & 7.2 & ----- & 7.507 & $\begin{array}{l}\text { Longitudinal } \\
\text { shear failure }\end{array}$ & Brittle \\
\hline $\mathrm{CS} 2 \mathrm{~s}$ & 59.1 & 6.6 & 70 & 17.8 & 19.2 & 2.90 & 10 & $\begin{array}{l}\text { Longitudinal } \\
\text { shear failure }\end{array}$ & Ductile \\
\hline $\mathrm{CS} 3$ & 90 & 21.4 & 105 & ----- & 53.5 & 2.50 & Zero & Flexural failure & Ductile \\
\hline $\mathrm{CS} 3 \mathrm{~s}$ & 72 & 11.8 & 108 & 2.86 & 56.11 & 4.75 & Zero & Flexural failure & Ductile \\
\hline
\end{tabular}

\subsection{Load-deflection relationships}

The trapezoidal shape and triangle shape of composite slab showed same trend and behaviour, where they underwent in three stages, the first stage before slip which showed linear relationship between load and deflection and the second stage after first slip where the load decrease with increase in deflation. The last stage showed redistribution in stress where the load increased with large deflection until the ultimate load after that the specimens failed by longitudinal shear failure. While the composite slab with $\mathrm{T}$-shape behave same other specimens until the first crack to showed large increase in deflection before failed by flexural failure. Figure 6 and figure 7 show the load-deflection response of specimens without and with shear connectors respectively. The load-deflection response of composite slab with trapezoidal shape in presence shear connectors (CS1s) was same trend and behavior in absence of shear connectors (CS1) but its deflection was less at yield and ultimate load than absence of shear connectors and that due to shear connectors act to delay the yield load as shown in the Figure 8. 
Whereas the composite slab with triangle shape in presence shear connectors (CS2s) showed same behavior in absence of shear connectors (CS2) until the first slip happened after that the load of composite slab without studs went down with large increase in deflection to showed brittle failure while the load in composite slab with studs (CS2s) went down with increase in deflection and then back up to show ductility behavior as shown in the Figure 9. Finally, the add shear connectors to the composite slab with T-shape did not effect on the deflection behavior of slab and that inducted the composite slab with T-shape does not need to shear connectors as shown in Figure 10.

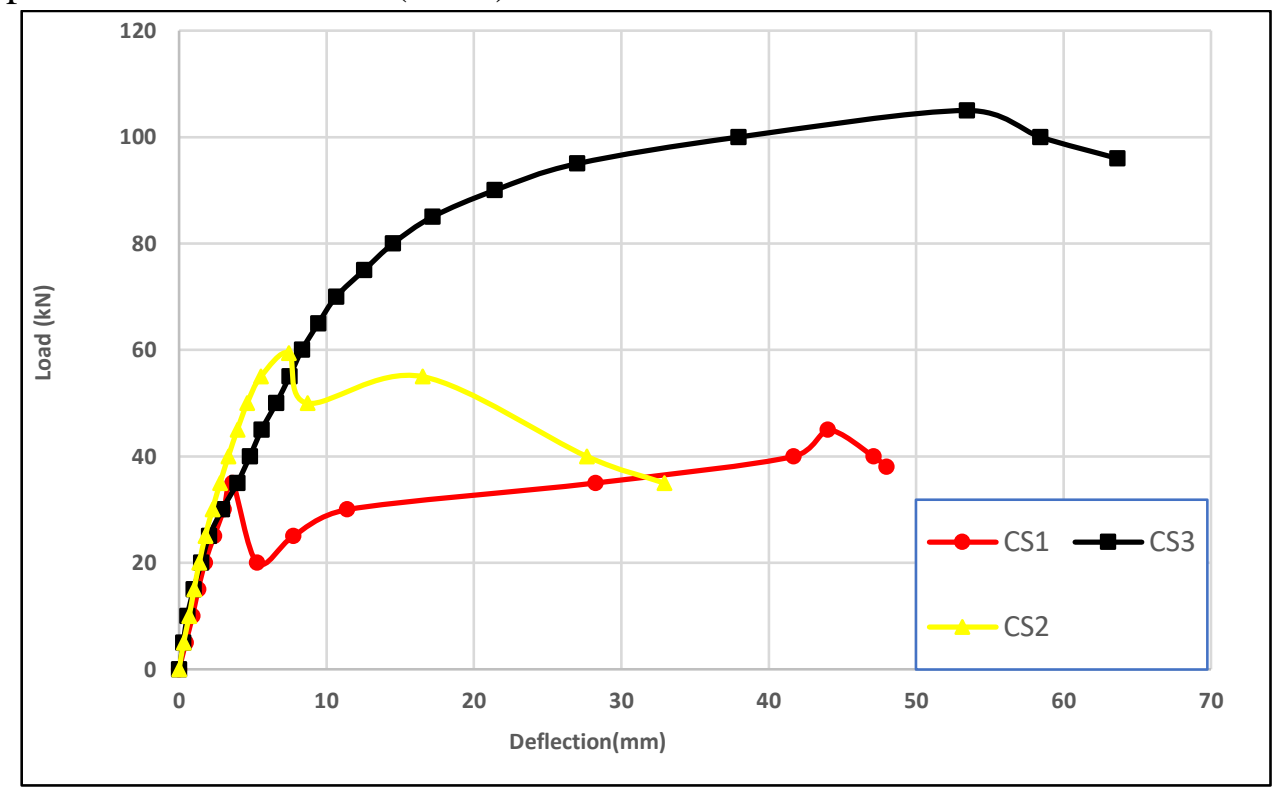

Figure 6. Load-deflection response of specimens without studs

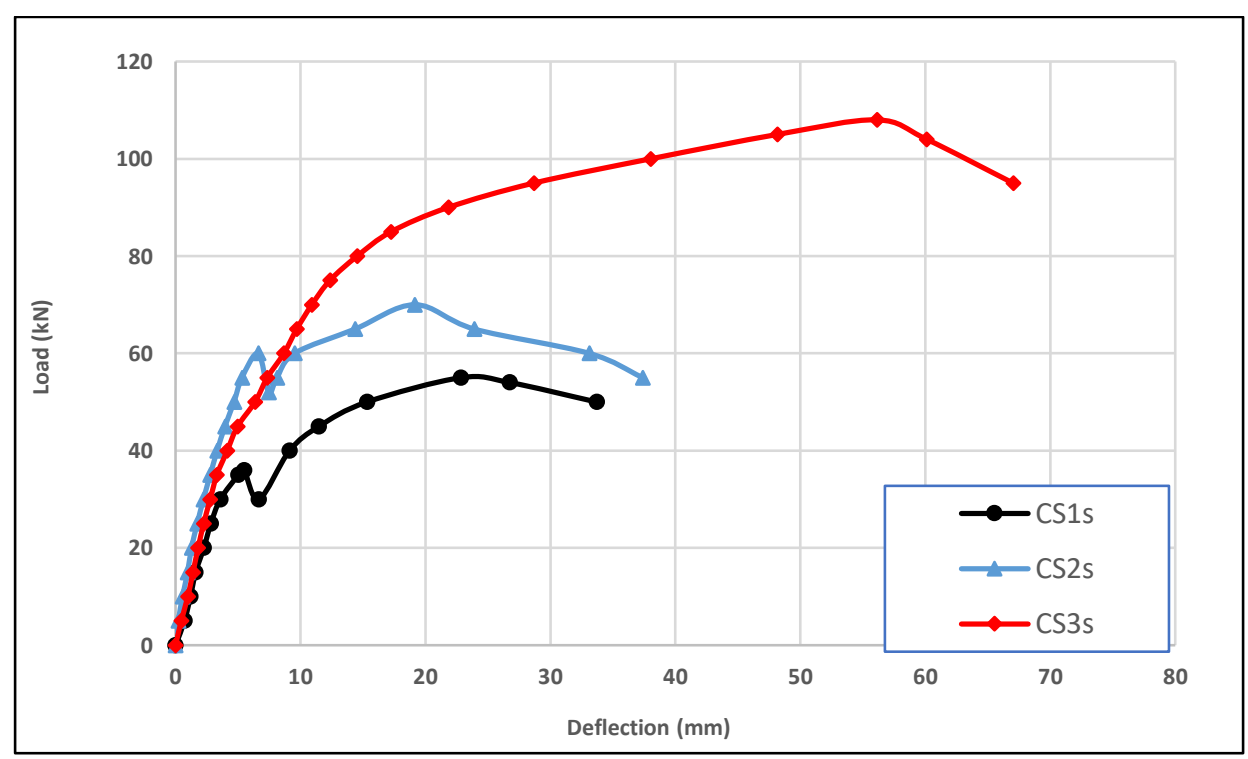

Figure 7. Load-deflection response of specimens with studs 


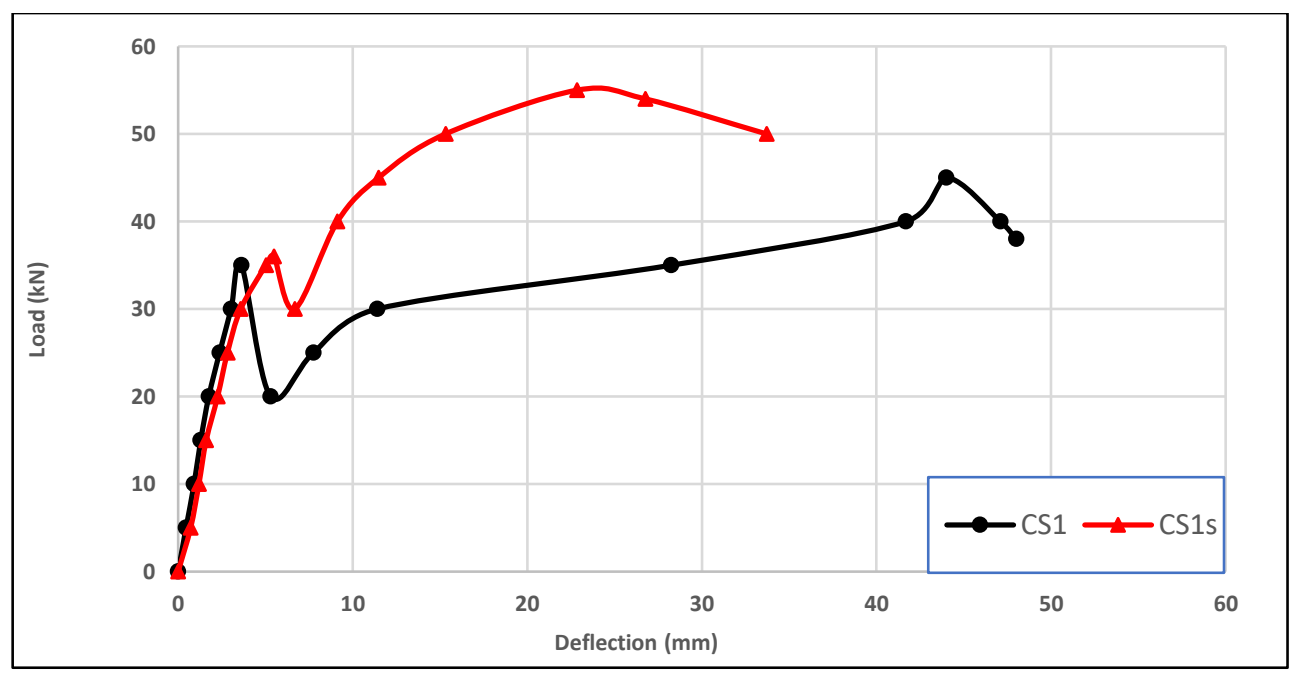

Figure 8. Load-deflection response of specimens with trapezoidal shape in presence and absence studs

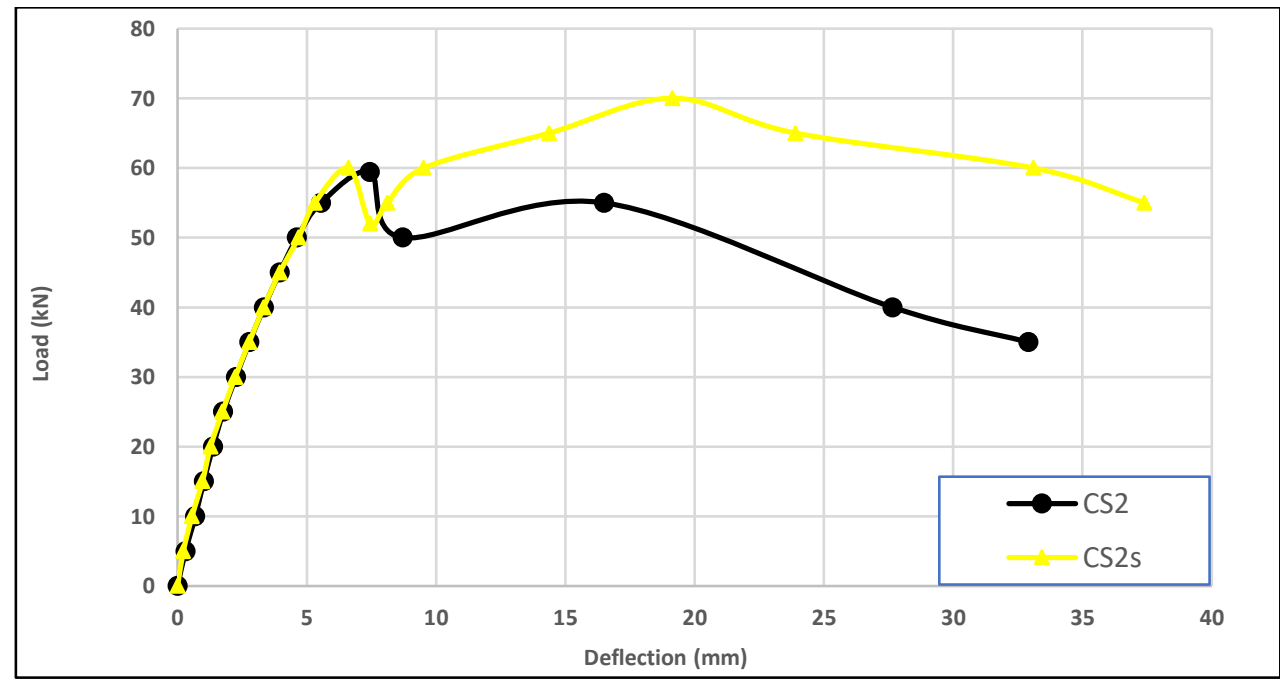

Figure 9. Load-deflection response of specimens with triangle shape in presence and absence studs

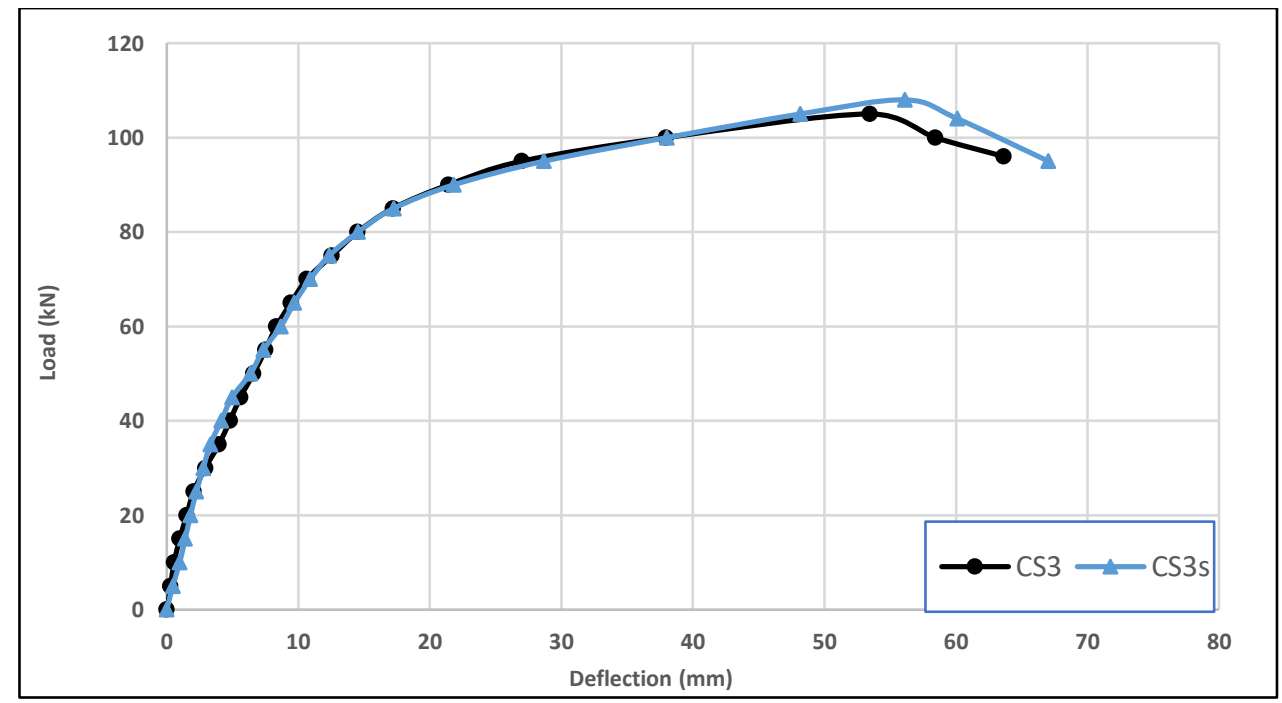

Figure 10. Load-deflection response of specimens with T-shape in presence and absence studs 


\subsection{Concrete compressive strain}

The compressive strain of composite slabs with trapezoidal shape, triangle shape and $\mathrm{T}$ shape in presence and absence of shear connectors are represents in figure 11 to figure 13. Where the compressive strain of composite slabs with trapezoidal shape showed same behavior but there is increase in development of strain in presence shear connectors after slip happened and that due to the shear connectors act to increase interlock which led to increase horizontal and transvers shear strength and delay separation between steel sheet and concrete, as the result the development of compression strain increased. Also, the composite slabs with Tshape showed same behavior and ultimate strain because the presence of shear connectors did not affect on the composite slab with T-shape while the composite slabs with triangle shape show different trend and behavior because the shear connectors act to increase connection and failure mode became ductile rather than brittle.

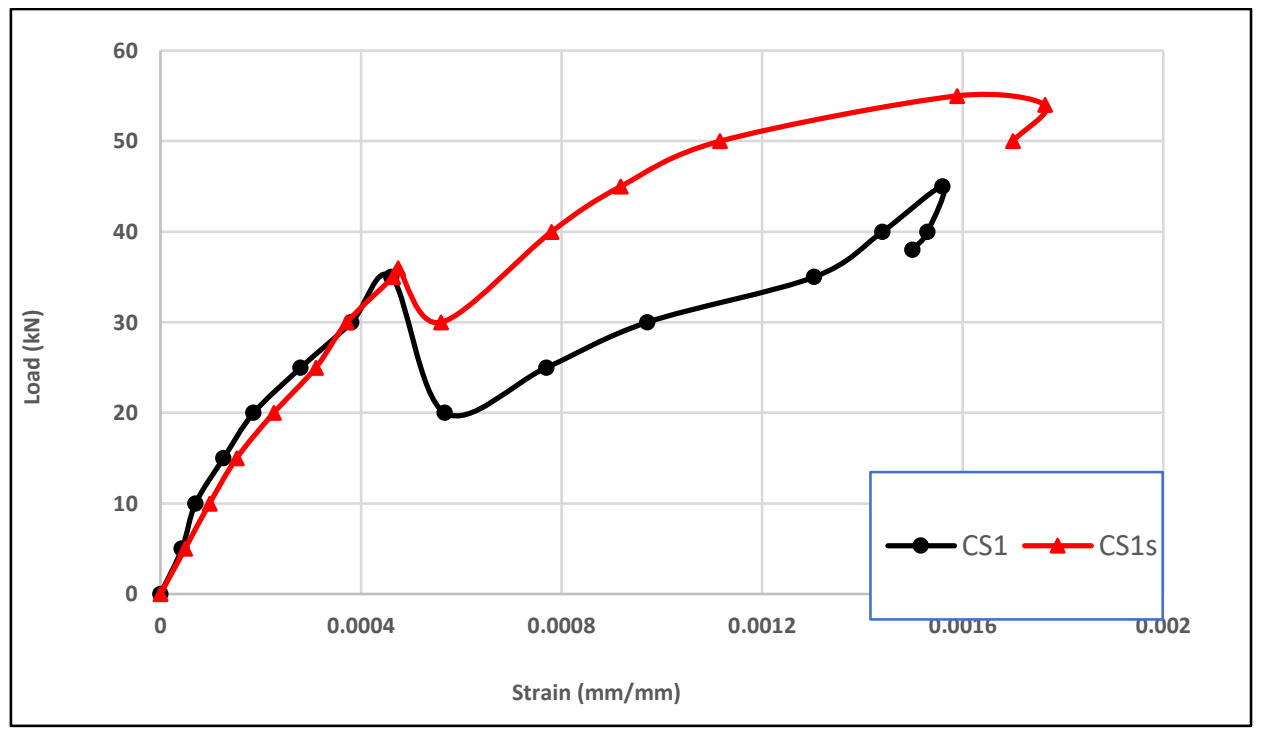

Figure 11. Concrete compressive strain development of trapezoidal shape in presence or absence studs

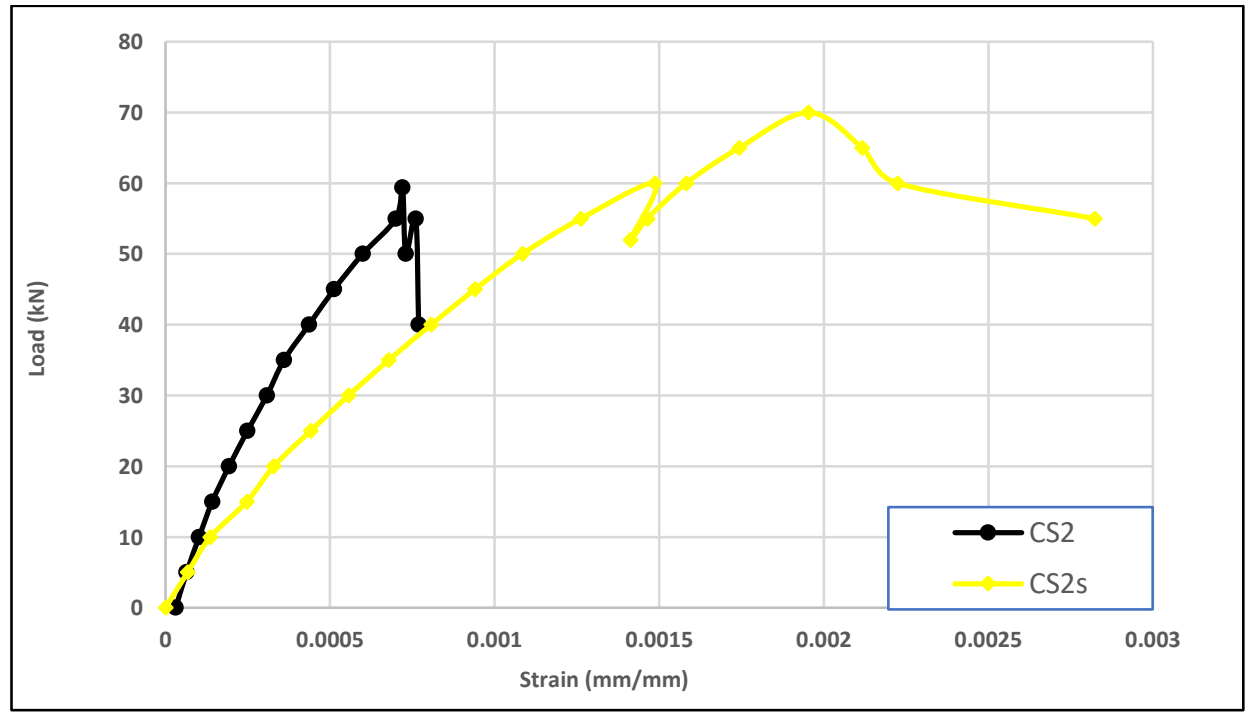

Figure 12. Concrete compressive strain development of triangle shape in presence or absence studs 


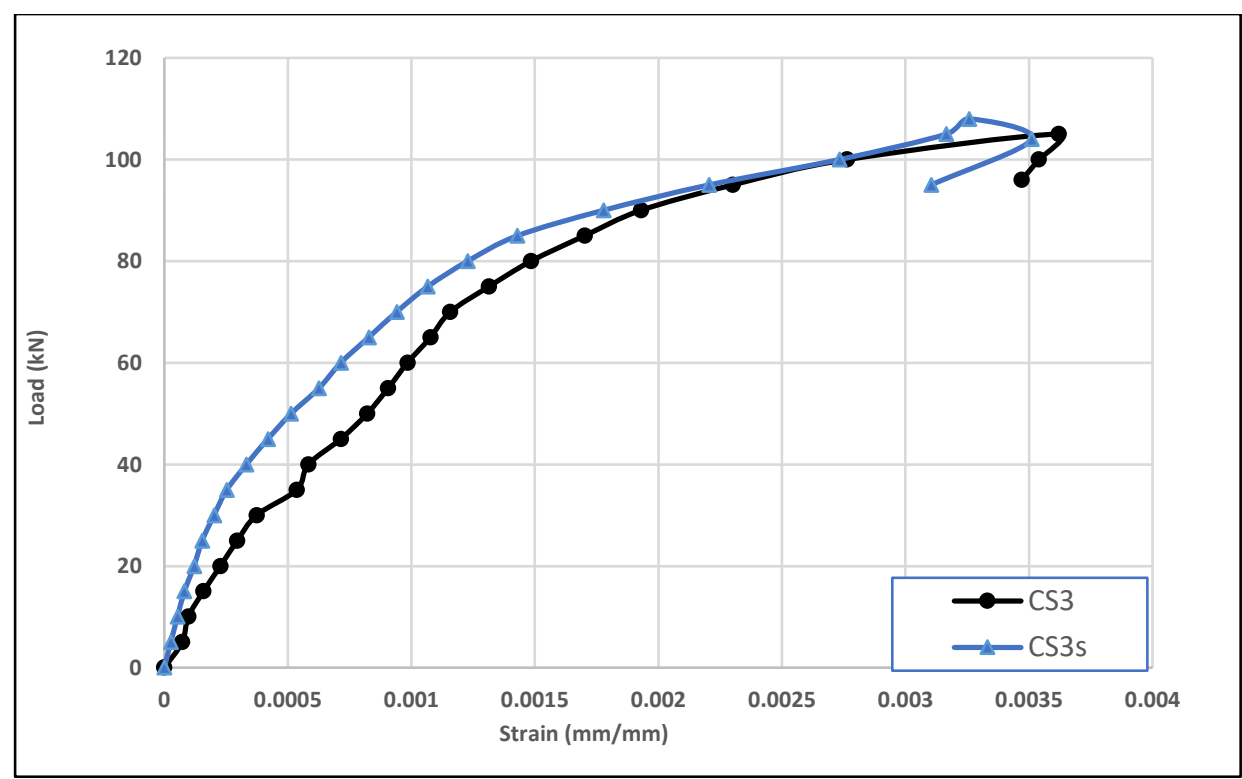

Figure 13. Concrete compressive strain development of T-shape in presence or absence studs

\subsection{Strain of profile steel sheet}

The tensile strain of composite slabs with $\mathrm{T}$ shape and Triangle shape were less than tensile strain of composite slab with trapezoidal shape at the same load especially at load beyond the service load and that due to the shape of profile steel sheet which have a great role in the composite action. The tensile strain of composite slabs in presence shear connectors were more developed than composite slabs without shear connectors because of the shear connectors act to increase composite action and improve the slip in transverse and longitudinal direction, that lead to increase the ultimate load and that made development in strain as shown in figure 14 to Figure 16.

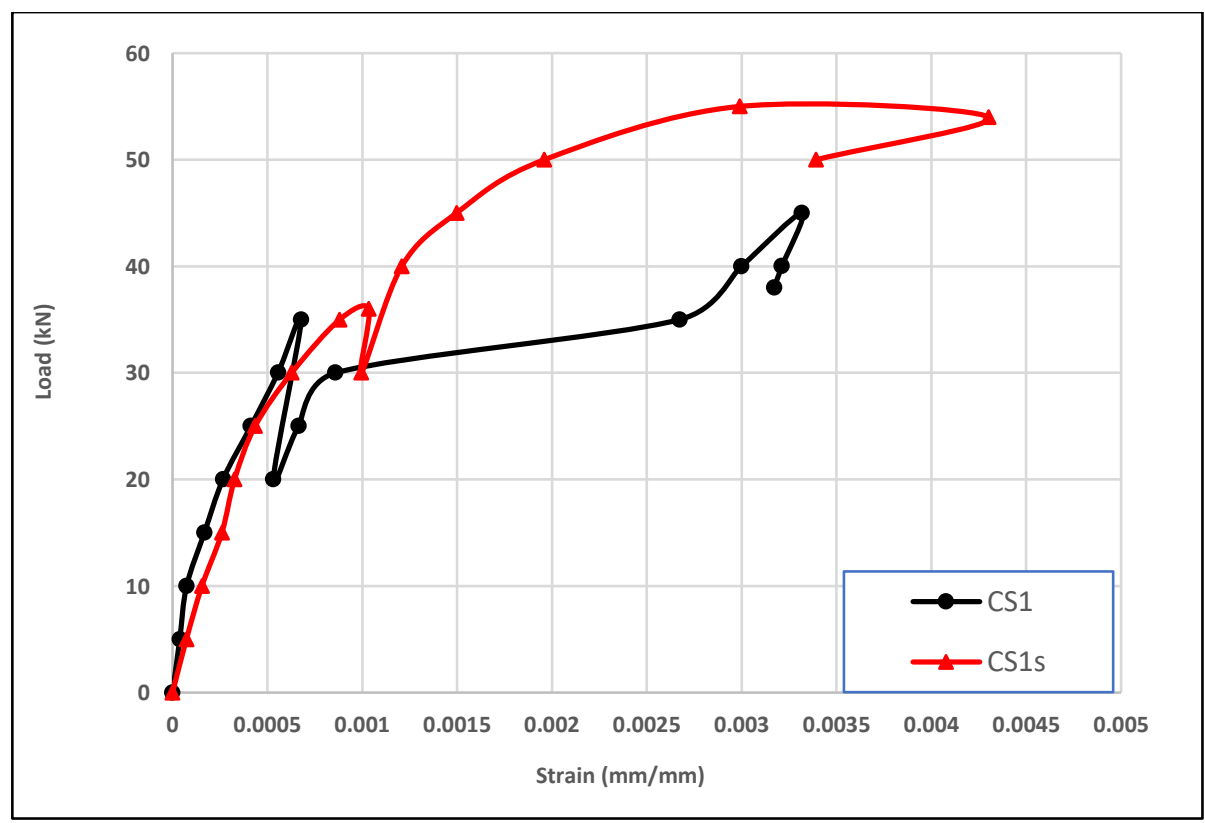

Figure 14. Tensile strain development of steel sheet trapezoidal shape in presence or absence studs 


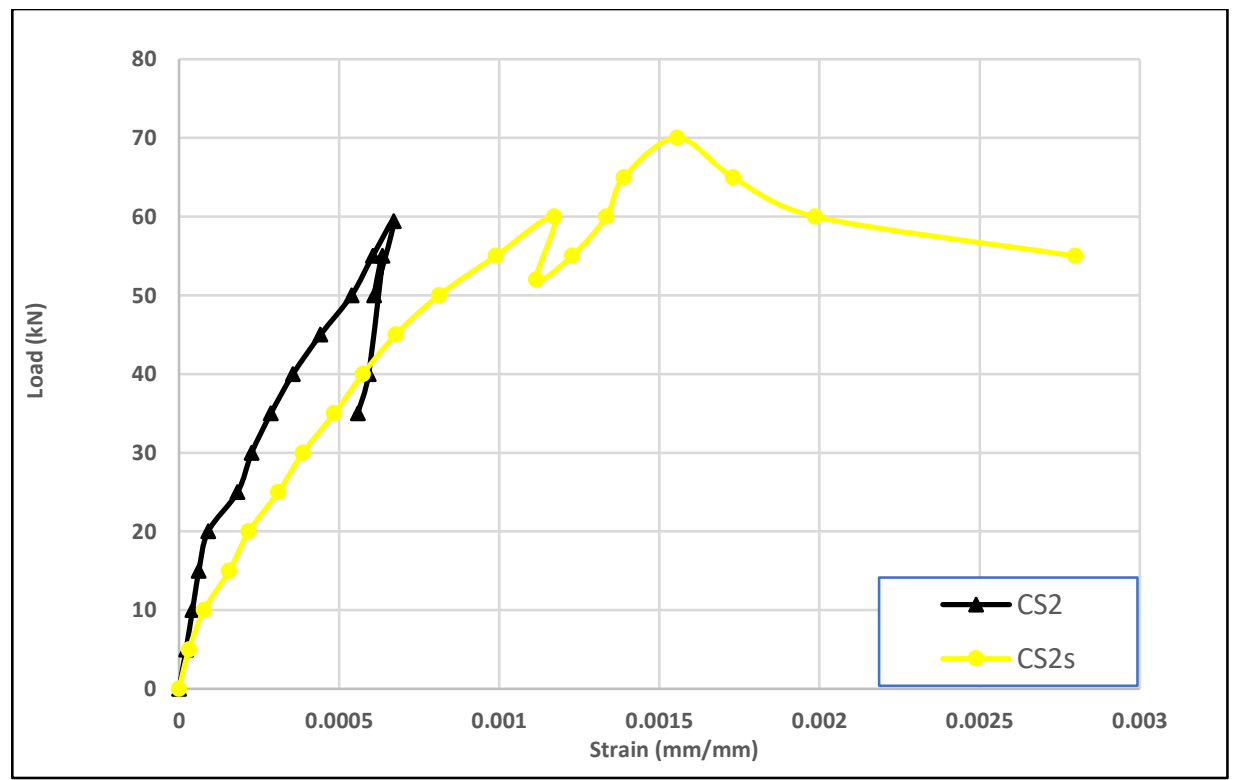

Figure 15. Tensile strain development of steel sheet in in triangle shape in presence or absence studs

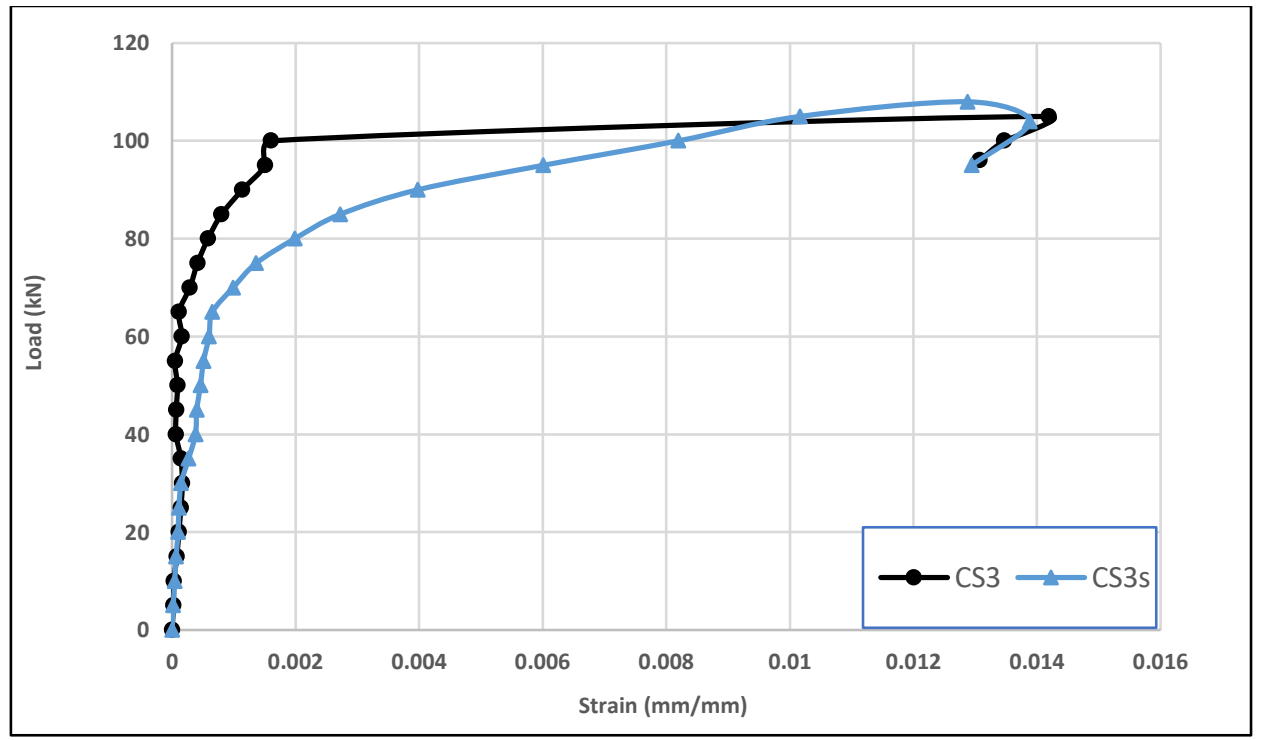

Figure 16. Tensile strain development of steel sheet in T-shape in presence or absence studs

\subsection{Horizontal end slip behavior of composite slabs}

The horizontal shear failure of the composite slab is said to be ductile if the load that caused failure exceeds the load which causes the first slip by 10\% (EN 1994-1-1: 2004) and according to Eurocode 4 requirements, all the composite slabs behave as ductile except specimen with triangle shape without shear connectors behave as brittle. The typical horizontal end slips between the steel sheet and concrete are presented in the figure 17. The slip in the slab specimens with T-shape is zero during all the stage of loading and that indicate the connection between profile steel sheet and concrete is complete interaction in presence or absence of shear connectors. whereas the horizontal end slip in the composite slabs with other shape were zero in early stage of loading but after the slippage starts, the rate of slip got higher and bond showed deterioration and then failed happened. Presence the shear connectors in the composite slabs with trapezoidal shape and triangle shape act to reduce development of slip in early stages of loading but the maximum end 
slip were more than specimens without shear connectors due the headed studs which act to increase the horizontal and transverse shear strength and that lead to increase interlock between profile steel sheet and concrete, as the result increase in development of load. Figure 18 and figure 19 show the end slip development in trapezoidal and triangle shape respectively.



(a) Trapezoidal shape

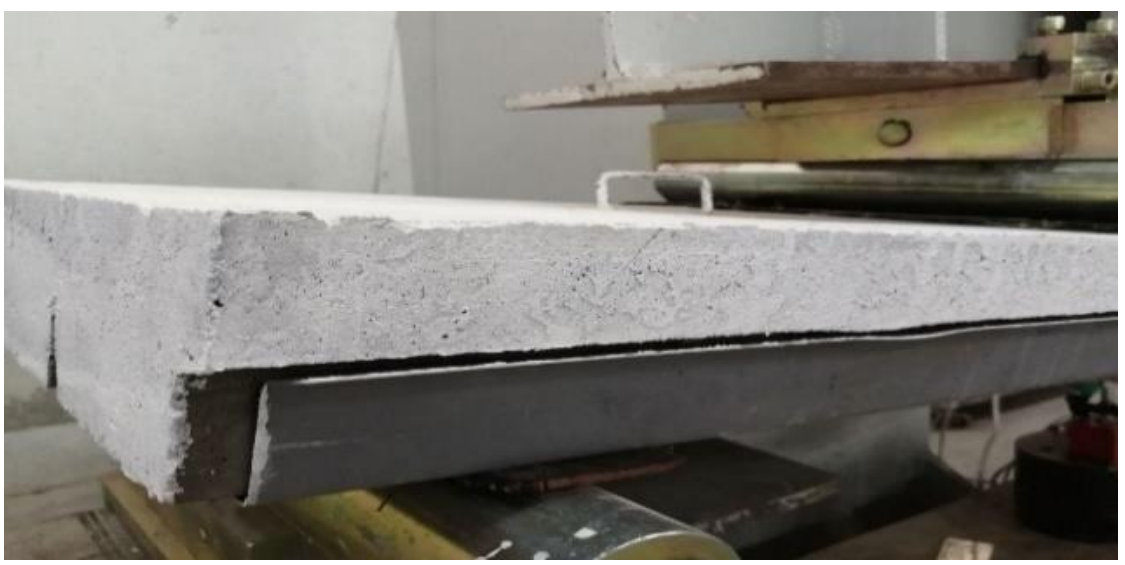

(b) Triangle shape

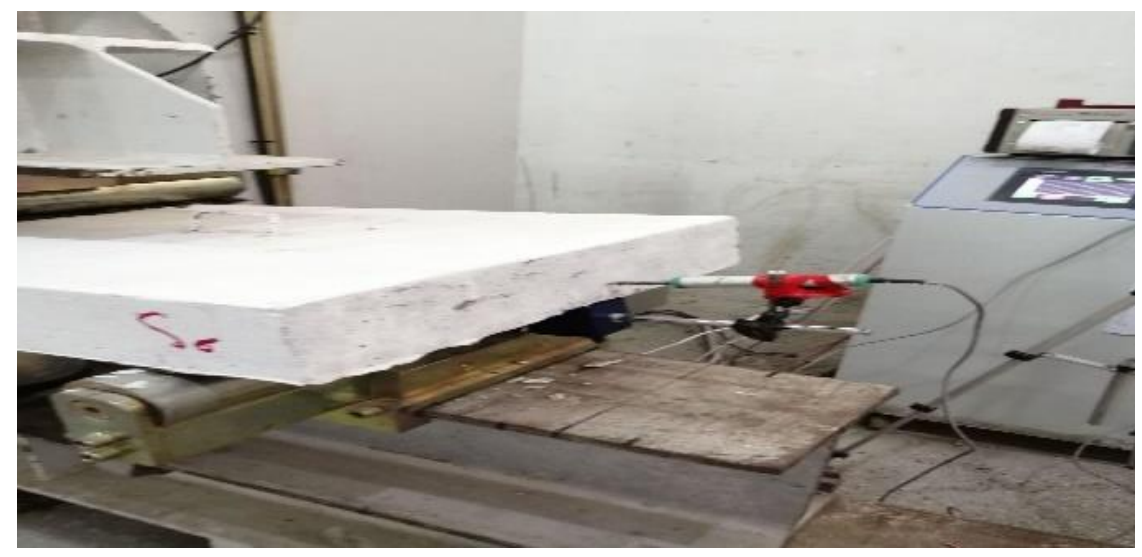

(c) Triangle shape

Figure 17. Slip between profile steel sheet and concrete 




Figure 18. Load-slip development of trapezoidal in presence or absence studs



Figure 19. Load-slip development of triangle shape in presence or absence studs

*The Slip in Specimen CS2s Cannot Read Because Technical Problem

\section{Mode of failure and crack patterns}

Figure 21 shows the crack distribution and mode of failure of composite slabs specimens under failure load. The composite slabs specimens that have $\mathrm{T}$ - shape in presence and absence of shear connectors failed by flexural failure and the first flexural crack was at $(40 \mathrm{kN}$ and $38 \mathrm{kN}$ ) respectively without any end slip.
While the composite slabs with other shape showed horizontal shear shear failure. The longitudinal shear failure can be recognized by the crack in the concrete under one of the load points, all the composite slabs specimens showed ductile behavior except specimen with triangle shape without shear connectors showed brittle failure according to [4]. 


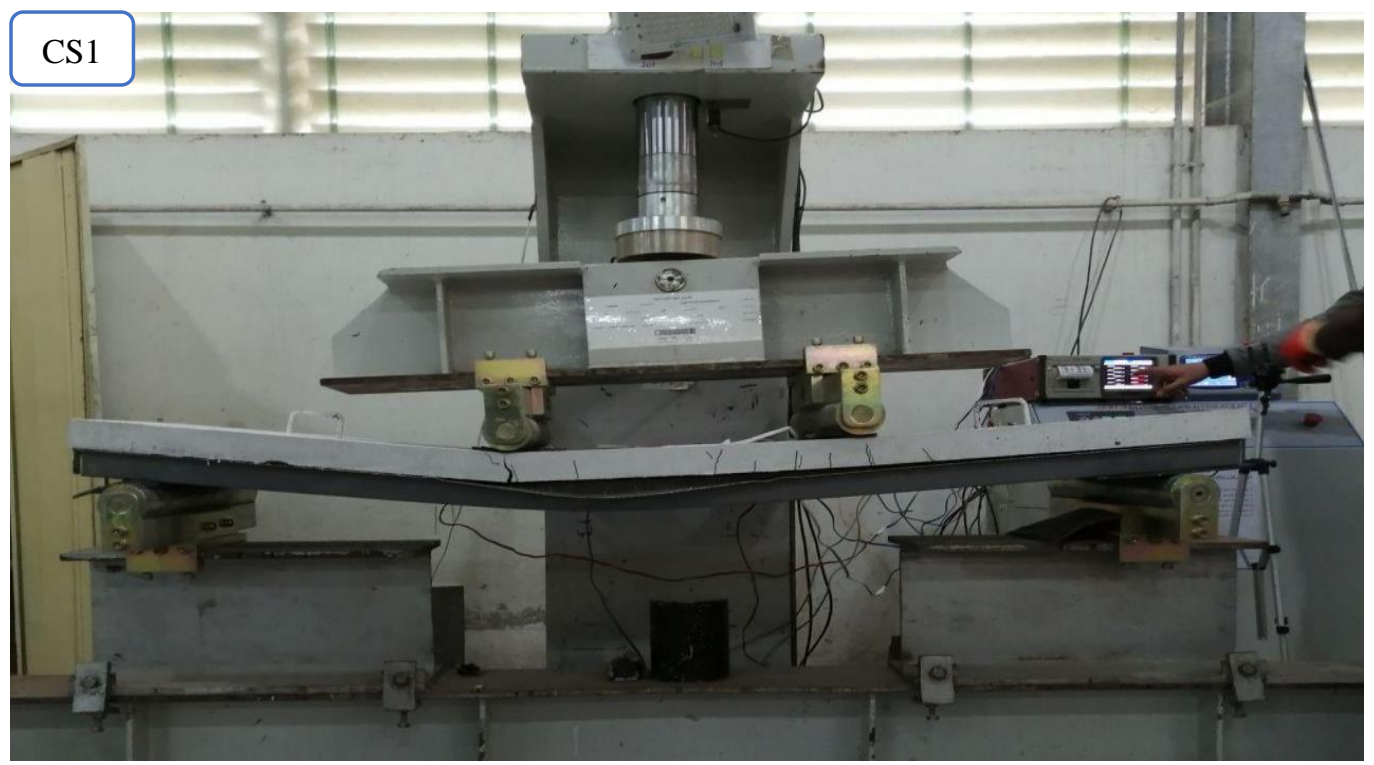

(a) Trapezoidal shape of composite slab without shear connectors

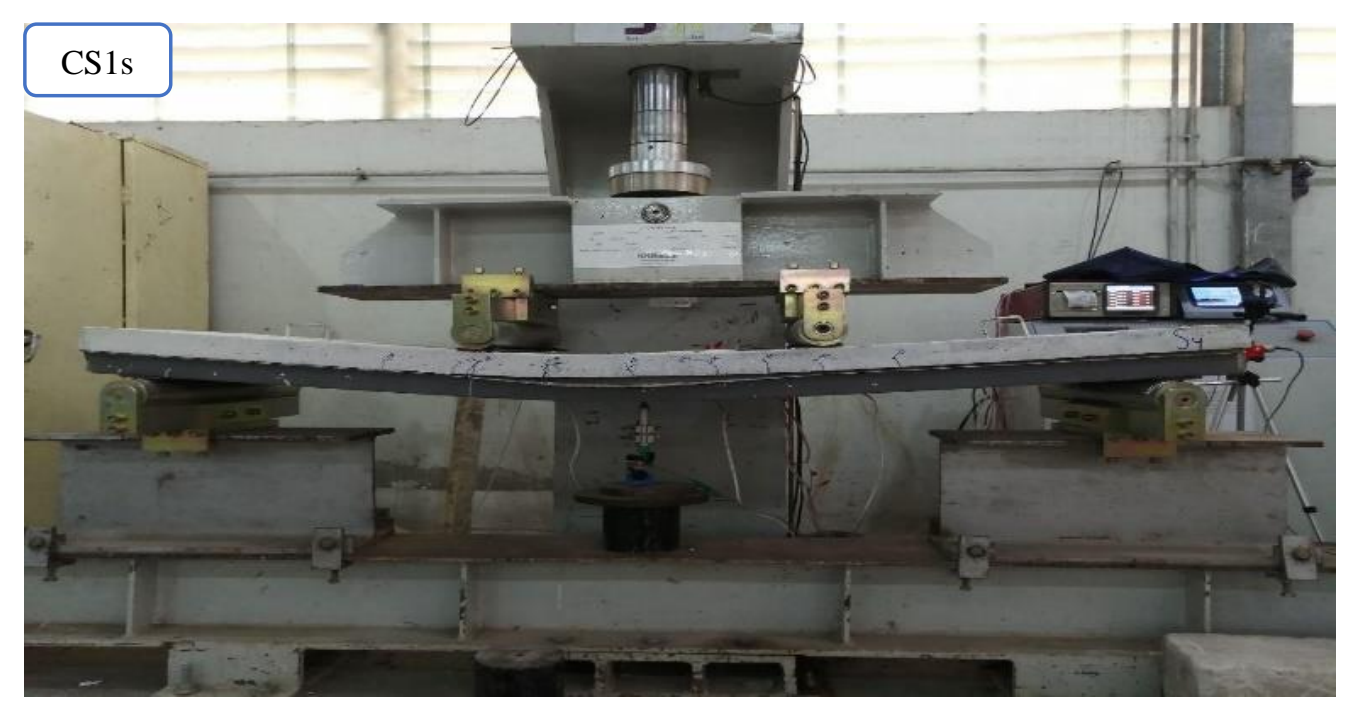

(b) Trapezoidal shape of composite slab with shear connectors

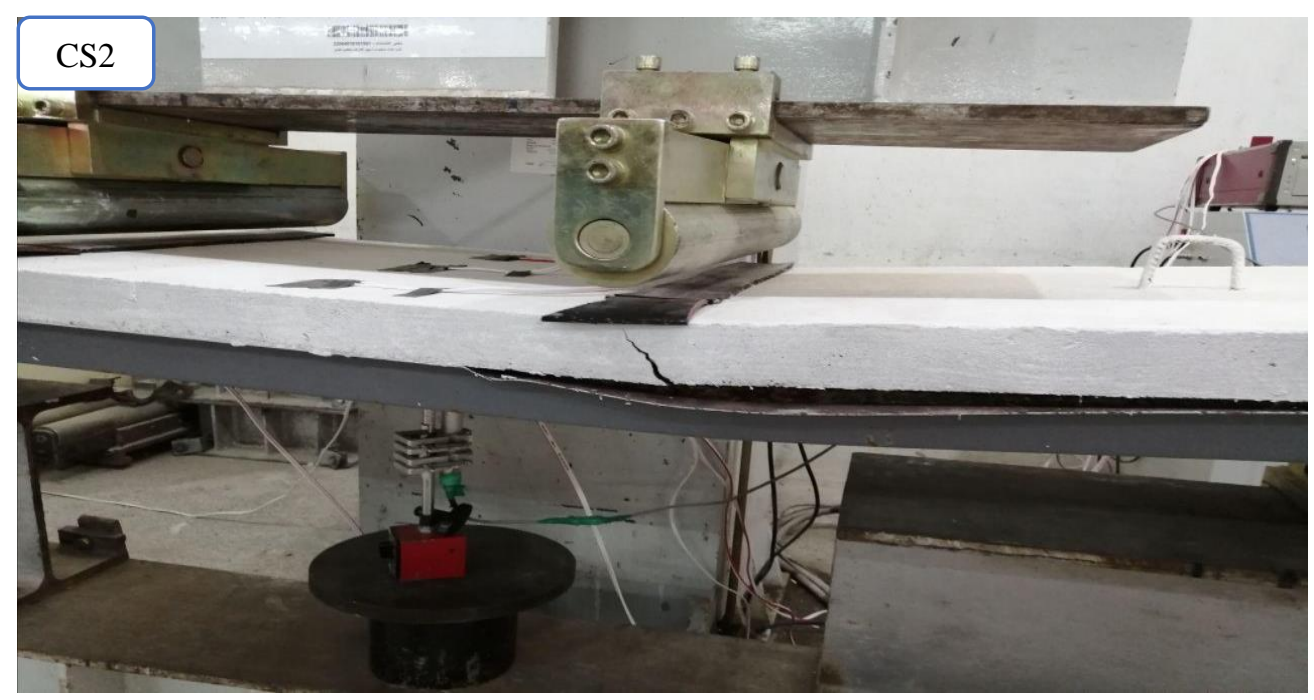

(c) Triangle shape of composite slab without shear connectors 


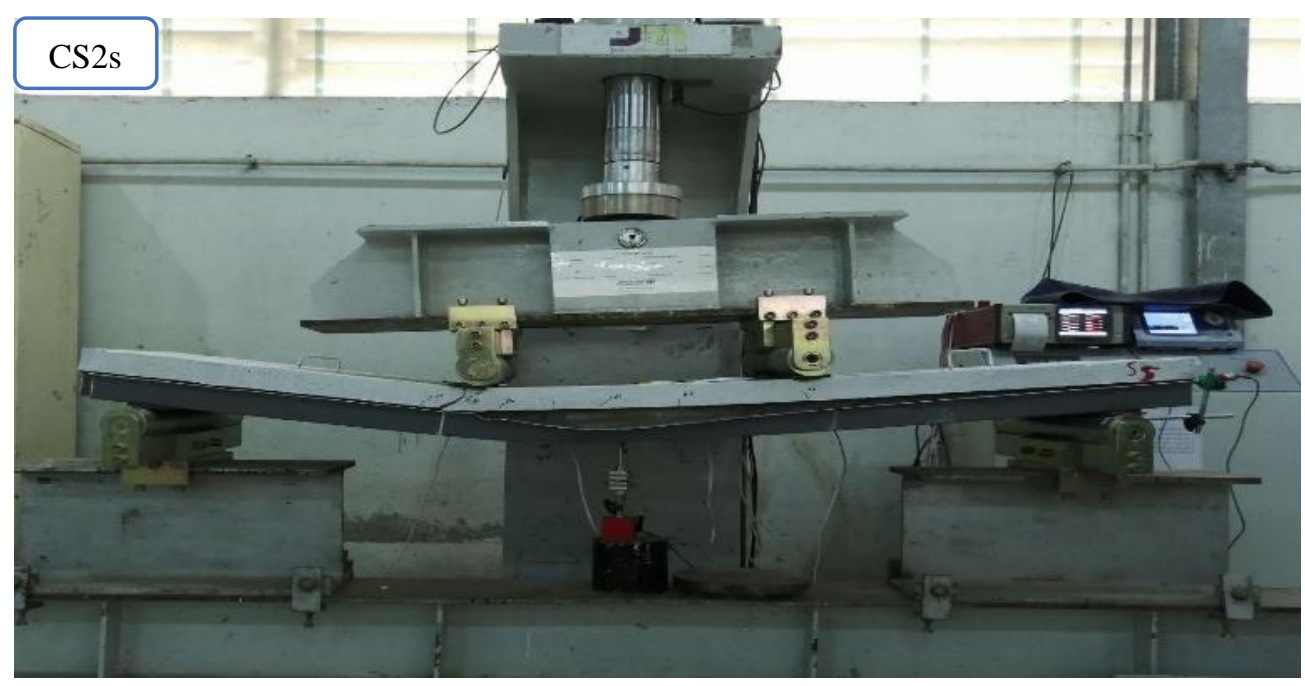

(d) Triangle shape of composite slab with shear connectors

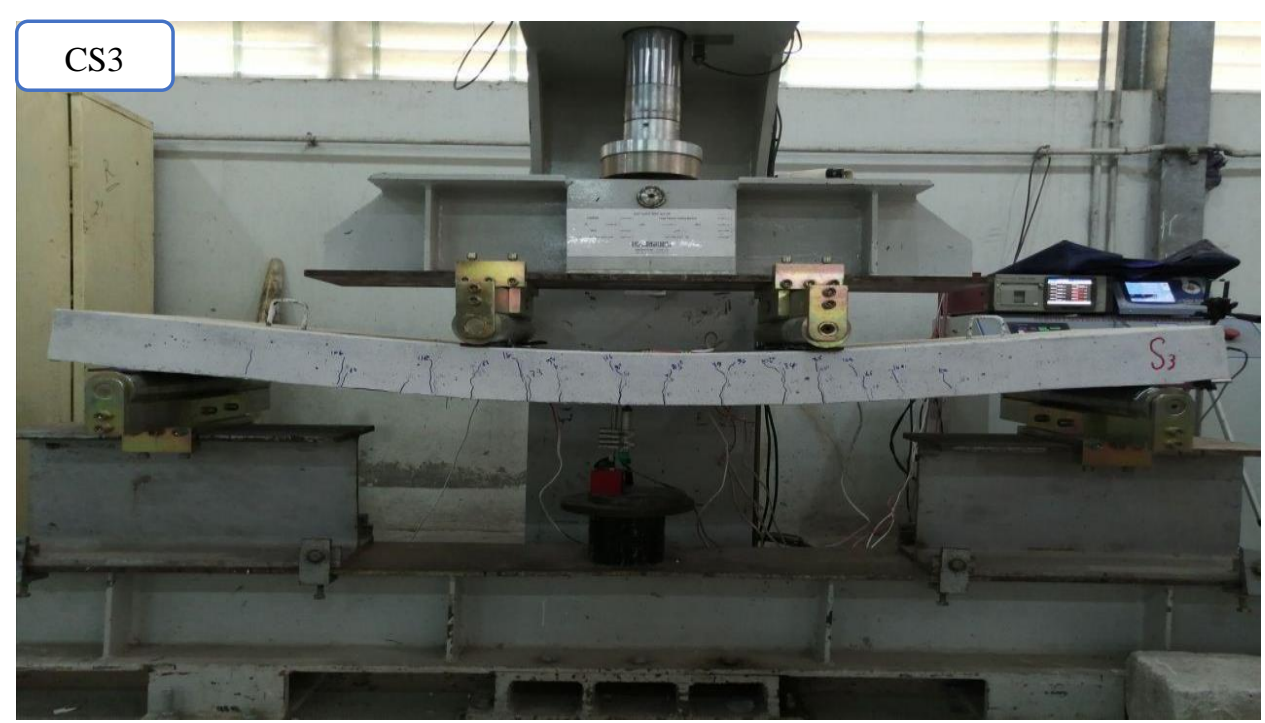

(e) Triangle shape of composite slab without shear connectors

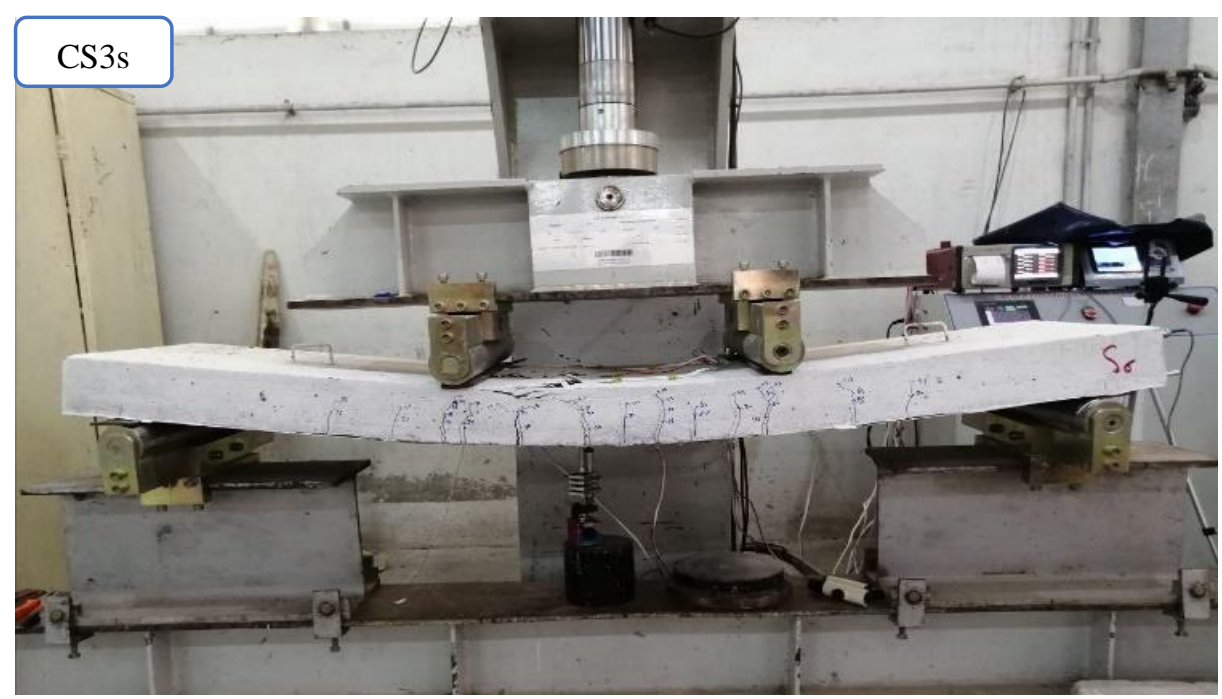

(f) Triangle shape of composite slab with shear connectors

Figure 20. Crack pattern and failure mode of slabs specimens 


\section{Conclusion}

From the results of the tested composite slabs specimens, the following conclusions can be drawn: -

- The presence shear connectors in composite slabs with trapezoidal shape and triangle shape act to increase ultimate load capacity by (22.2\% and $17.8 \%)$ respectively as compared with composite slabs without shear connectors while the effect of adding shear connectors to the composite slab with T-shape was very little or can be neglected.

- The adding shear connectors to the composite slabs with trapezoidal shape and triangle shape lead to decrease the deflection after slip happened as compared with the same load while the deflection in the composite slabs with T-shape was approximately same in presence and absence of shear connectors.

- The development of strain in composite slabs with trapezoidal shape and triangle shape in presence shear connectors were more than absence of shear connectors while the ultimate strain in composite slab with $\mathrm{T}$ shape was approximate same in presence and absence of shear connectors.

- The adding shear connectors to composite slabs in specimens with trapezoidal shape and triangle shape act to development of maximum end slip to $6.404 \mathrm{~mm}$ and $10 \mathrm{~mm}$ respectively while the slip in specimens with T-shape was zero in all the stage o loading.

- The composite slabs which have Triangle shape failed by flexural failure and showed full interaction whereas the composite slabs which have trapezoidal shape and triangle shape failed by horizontal shear failure and showed partial interaction.

\section{References}

[1] Eurocode 4. (2004). Design of composite steel and concrete structures - Part 1-1: General rules and rules for buildings. European Committee for Standardization, Brussels.

[2] Penza, A. (2010). Composite Slabs with Lightweight Concrete. Politecnico Di Milano, Milano.
[3] Rackham, J. W., Couchman, G. H., \& Hicks, S. J. (2009). Composite Slabs and Beams using Steel Decking: Best Practice for Design and Construction. The Metal Cladding \& Roofing Manufacturers Association in partnership with The Steel Construction Institute, Ascot.

[4] Johanson, R. (1994), Composite structure of steel sheet and concrete. Volume 1(beams; slabs; columns and frame for buildings.). Blackwell Scientific Publications, Oseny Mead, Oxford.

[5] Ahmed, S. M., Avudaiappan, S., Sheet, I. S., Saavedra Flores, E. I., Pina, J. C., Yanez, S. J., \& Guzmán, C. F. (2019). Prediction of longitudinal shear resistance of steel-concrete composite slabs. Engineering Structures, 193, 295-300

[6] Shobaki I. The Behaviour of Profiled Steel Sheet/Concrete Composite Slabs Ph D. Thesis Salford (UK): University of Salford; 2000. p. 1 275.

[7] N. Seres (2012) "Behaviour and resistance of concrete encased embossments in composite slabs" $\mathrm{Ph}$. D. Thesis, Budapest University of Technology and Economics, Budapest, pp 1-106

[8] Lee, C. H., Mansouri, I., Kim, E., Ryu, J., \& Woo, W. T. (2019). Experimental analysis of one-way composite steel deck slabs voided by circular paper tubes: Shear strength and moment- shear interaction. Engineering Structures, 182, 227-240.

[9] Lakshmikandhan, K. N., Sivakumar, P., Ravichandran, R., \& Jayachandran, S. A. (2013). Investigations on efficiently interfaced steel concrete composite deck slabs. Journal of structures, 2013.

[10] Siva, A., Senthil, R., \& Swaminathan, S. Assessment of longitudinal shear strength of Composite deck slab.

[11] Burnet, M. J., \& Oehlers, D. J. (2001). Rib shear connectors in composite profiled slabs. Journal of Constructional Steel Research, 57(12), 1267-1287. doi:10.1016/s0143-974x (01)00038-4

[12] Lakshmikandhan, K. N., Sivakumar, P., Ravichandran, R., \& Jayachandran, S. A. (2013). Investigations on Efficiently Interfaced Steel Concrete Composite Deck Slabs. Journal of Structures, 2013, 1-10. doi:10.1155/2013/628759

[13] EFNARC, F. (2002). Specification and Guidelines for Self-Compacting Concrete. European 29 Federation of National Associations Representing producers and applicators of specialist 30 building products for Concrete (EFNARC).

[14] STM A370-17, Standard Test Methods and Definitions for Mechanical Testing of Steel Products. 